\title{
Successive Saccharification of Waste Paper as a Resource for Bio-product Development
}

\author{
K.M.P. Mokatse and J.P.H. van Wyk $\dagger$ \\ Department of Pharmacology and Therapeutics, Sefako Makgatho Health Sciences University, Ga-Rankuwa, South Africa \\ †Corresponding author: J.P.H. van Wyk; bioenergy.res@gmail.com
}

\section{Nat. Env. \& Poll. Tech.} Website: www.neptjournal.com

Received: $24-04-2020$

Revised: $30-06-2020$

Accepted: 16-07-2020

Key Words:

Saccharification

Waste paper

Trichoderma viride

Cellulase

\begin{abstract}
Environmental pollution and the exploitation of fossil-based products are topical issues that should be a matter of concern to the global population. The production of bio-based substances from waste biomass is a way to reduce the consumption of fossil fuels and limit environmental pollution. Enzymatic catalysed saccharification of cellulose is an important step for the bio-conversion of biomass such as waste paper into glucose that could be utilized as a feedstock for the production of value added bioproducts and this process can also be considered as an alternative route of waste management. During this study, fresh cellulase enzyme from Trichoderma viride was incubated separately with seven different waste paper materials during twelve successive incubation periods of $2 \mathrm{~h}$ each. The amount of sugar released from each paper material during each incubation period was determined. The highest sugar concentration released from each paper materials was produced during the first incubation period except the filter paper for which the highest amount of sugar was produced during the $9^{\text {th }}$ period of incubation. During these optimum sugar producing incubation periods the highest total sugar concentration was released from brown envelope paper $\left(3.3 \mathrm{mg} \cdot \mathrm{mL}^{-1}\right.$ followed by foolscap paper (3.0 mg. mL $\left.{ }^{-1}\right)$ and office paper $\left(2.8 \mathrm{mg} \cdot \mathrm{mL}^{-1}\right)$ while the lowest amount of sugar was released from Pick 'n Pay paper $\left(0.6 \mathrm{mg} \cdot \mathrm{mL}^{-1}\right)$. The relative saccharification percentage was also calculated which showed that filter paper produced the highest amounts of sugar followed by newspaper, and foolscap paper with advertising paper from a retailer. Pick'n Pay offered the highest resistance towards cellulase catalysed bio-conversion into sugar.
\end{abstract}

\section{INTRODUCTION}

Globally the accumulation of municipal solid waste (MSW) amounts to 1300 tons per year with solid waste contributing approximately $3 \%$ of the total greenhouse gas emissions worldwide, which makes it as one of the biggest contributors to global warming and climate change (Ndlovu \& Van Wyk 2019). High amounts of solid waste and its improper management worsens air quality in cities which affects the health of human beings negatively (Tahir et al. 2015).

Cellulosic waste biomass such as sawdust, agricultural residues, and municipal solid waste (waste paper) are quite cheap and abundant alternative substrates for bio-product development (Canilha et al. 2013). Paper materials can be categorized as useful commodities because paper is a way to present information, can act as a protective agent and also serves as a packaging material (Van Wyk et al. 1999). The large consumption of different types of papers such as newspaper, office paper and advertising paper on a daily basis indicate that paper is an important commodity that is used worldwide and affects human life (Wu \& Cheng 2005). Waste paper is a heterogeneous mixture of plant material, especially which is rich in cellulose (50-60\%) (Veluchamy 2017), a glucose biopolymer that constitutes thousands of glucose units and hemicellulose that is composed of two kinds of pentoses (xylose and arabinose) and three kinds of hexoses (glucose, mannose and galactose) (Saini et al. 2015). Lignin which is another biopolymer in paper materials is made up of aromatic compounds only which can't be easily hydrolysed as it works as a glue cementing cellulose and hemicellulose together (Seidl \& Goulart 2016).

The hydrolysis of cellulose can be performed in different ways, either by strong acids and bases or by an enzymatic catalysed process using cellulase as the hydrolytic agent. The enzymatic process favours having a selection of the substrate and less production of by-products under mild conditions (Hamelinck et al. 2005). Cellulase is a hydrolytic, multi-component enzyme system responsible for the saccharification of cellulose. The complete hydrolysis of cellulose into glucose can be achieved synergistically by a combination of three types of cellulases namely, endoglucanases which cleave internal glucosidic bonds in the cellulose structure, exoglucanases which are responsible to cleave cellobiosyl units from the end of a cellulose chain and the third enzymatic 
component is a $\beta$-glucosidase enzyme that is responsible for the removal of glucose units from cello-oligosaccharides and the hydrolysis of cellobiose into glucose (Jeoh et al. 2006, Kim et al. 1998).

The hydrolysis of waste cellulose into fermentable sugars for the production of bio-products such as bioethanol and bio-pharmaceuticals, is an important step in the use of alternative feedstocks and thus reduces pollution caused by solid waste accumulation. Industries and businesses are the biggest users of paper which amounts to $52 \%$ of the total papers produced and it is estimated that about $10 \%$ of recovered waste paper comes from offices (Rodriguez et al. 2017). During the current investigation T. viride cellulase was used to successively hydrolyse the cellulose content of seven different paper materials namely, office paper, foolscap paper, newspaper, filter paper, brown envelope paper and advertising paper from retailers, Pick 'n Pay and Woolworths into fermentable sugars such as glucose. During the successive cellulase treatment of the waste paper materials, the produced sugar was removed from the incubation mixture after each incubation period. The regular removal of sugars from the incubation mixture was aimed at limiting end-product inhibition and regularly adding fresh cellulase could assist in constructing a sugar production profile from different cellulose materials when treated regularly and successively with fresh $T$. viride cellulase enzymes.

\section{MATERIALS AND METHODS}

\section{Waste Paper Materials and Cellulase Enzyme}

Seven different types of paper materials were used as cellulose substrates during the $T$. viride cellulase catalysed degradation of these waste cellulose materials into fermentable sugars such as glucose. These paper materials included, office paper, foolscap paper, Pick 'n Pay advertising paper, Woolworths advertising paper, newspaper, brown envelope paper and filter paper that were prepared as circular discs of $6.0 \mathrm{~mm}$ in diameter.

\section{Cellulase Catalysed Saccharification of Waste paper}

Twenty pieces of each paper material were transferred into a test tube and then mixed with $800 \mu \mathrm{L}$ of tris-buffer $(0.5$ mL.dm $\left.{ }^{-3}, \mathrm{pH} 5.0\right)$ and $200 \mu \mathrm{L}$ of the T. viride cellulase enzyme solution ( $2 \mathrm{mg} \cdot \mathrm{mL}^{-1}$, prepared in the buffer solution). These paper-enzyme mixtures were incubated for $2 \mathrm{~h}$ at $50^{\circ} \mathrm{C}$ and thereafter centrifuged for $15 \mathrm{~min}$ at $4000 \mathrm{rpm}$ with the supernatants transferred into clean test tubes and used to determine the amount of sugar released from each paper material during the cellulase catalysed action. The non-degraded paper materials (precipitate after centrifugation) were kept at $4^{\circ} \mathrm{C}$ for a re-incubation with fresh $T$. viride cellulase during a subsequent successive treatment of $2 \mathrm{~h}$. Successive treatments were repeated for 12 consecutive incubation intervals and all incubations with the distinctive paper materials were performed in triplicate (Ndlovu \& Van Wyk 2019).

\section{Determination of Reducing Sugars}

The amount of sugars released from various paper materials (present in the supernatant after centrifugation) during successive treatment with the T. viride cellulase was determined by adding $1500 \mu \mathrm{L}$ of DNS solution to each supernatant according to the method described by Miller (Miller 1959). To accelerate the colour formation, each solution was placed in a boiling water bath for a period of $10 \mathrm{~min}$ and thereafter cooled in ice water. The cooled and coloured samples were read on a spectrophotometer (Shimadzu, Kyoto, Japan) at $520 \mathrm{~nm}$ in order to determine the amount of reducing sugars released from each paper material. The concentration of sugars released during each of the successive incubation periods was calculated by using a calibration curve constructed with glucose standards and expressed as mg. $\mathrm{mL}^{-1}$.

\section{Calculation of Percentage Saccharification}

The percentage saccharification of each paper material caused by the cellulase enzyme was calculated as described by Alrumma (2016), where the percentage saccharification is equal to the concentration of reducing sugars $\left(\mathrm{mg} \cdot \mathrm{mL}^{-1}\right)$ divided by the initial substrate concentration $\left(\mathrm{mg} \cdot \mathrm{mL}^{-1}\right) \times$ $0.9 \times 100$. The factor 0.90 was used to convert polysaccharide to monosaccharide accounting for water uptake during hydrolysis.

\section{RESULTS AND DISCUSSION}

Rising environmental problems such as the accumulation of solid waste and release of carbon dioxide and other toxic compounds into the air as a result of fossil fuel combustion will force the global community to identify and develop renewable resources that could be used as feedstocks for the synthesis of many chemical substances. A possible solution to these negative environmental issues could be the development of bio-products such as bio-ethanol, biodiesel and other biochemicals from the cellulose component of organic waste like the waste paper. To produce bio-products, the cellulosic component of biomass or waste cellulose has to be hydrolysed by cellulolytic enzymes producing glucose which is finally fermented into bio-products (Mazzoli 2012). The different types of biomass available show high recalcitrance to enzymatic rupture due to the barrier properties of lignin and other admixtures. Most of the different types of waste papers and boards such as newspaper, packaging paper, 
cardboard, corrugated board, coated or impregnated paper and the board can contain not only lignin, but other barrier components such as waxes, fats, rubbers, synthetic polymers and resins, and hydrophobic substances that prevent the enzymatic cleavage of the paper materials (Loelovich 2014).

When office paper (Fig. 1) was exposed to successive treatment with $T$. viride cellulase, a sugar concentration of 2.8 $\mathrm{mg} \cdot \mathrm{mL}^{-1}$ was produced during the first incubation period of $2 \mathrm{~h}$. The amount of sugar released from office paper during the second incubation period was lower at a concentration of $1.0 \mathrm{mg} . \mathrm{mL}^{-1}$. The tendency of decreasing sugar production during successive treatment continued until the $6^{\text {th }}$ incubation period ( $12 \mathrm{~h}$ of degradation) when a sugar concentration of $0.4 \mathrm{mg} . \mathrm{mL}^{-1}$ was released from this paper material. During the rest of the incubation periods, the amount of sugar released stayed relatively constant as it varied between 0.4 $\mathrm{mg} \cdot \mathrm{mL}^{-1}$ and $0.6 \mathrm{mg} \cdot \mathrm{mL}^{-1}$. The rate at which the amount of sugar production decreased during the first six successive treatments was calculated at $-0.2 \mathrm{mg} \cdot \mathrm{mL}^{-1} \cdot \mathrm{h}^{-1}$.
All other six paper materials degraded with the T. viride cellulase enzymes exhibited almost the same tendency in sugar production with the highest sugar concentration releasing during the first incubation period. When foolscap paper (Fig. 2) was degraded, a sugar concentration of 3.0 $\mathrm{mg} \cdot \mathrm{mL}^{-1}$ was released which decreased to a concentration of $0.4 \mathrm{mg} \cdot \mathrm{mL}^{-1}$ after $14 \mathrm{~h}$ ( $7^{\text {th }}$ incubation period) of cellulase treatment. During the rest of the incubation periods, a relatively constant amount of sugar $\left(\mathrm{mg} \cdot \mathrm{mL}^{-1}\right)$ was released during each incubation period from $14 \mathrm{~h}$ to $21 \mathrm{~h}$. With brown envelope paper (Fig. 3) exposed to the enzymatic catalysed degradation the amount of sugar released during the first incubation period was $3.3 \mathrm{mg} . \mathrm{mL}^{-1}$ which decreased at a rate of $-0.21 \mathrm{mg} \cdot \mathrm{mL}^{-1} \cdot \mathrm{h}^{-1}$ until a concentration of $0.4 \mathrm{mg} \cdot \mathrm{mL}^{-1}$ was released after $14 \mathrm{~h}$ of treatment. During the rest of the incubation period, the sugar concentration varied between $0.7 \mathrm{mg} \cdot \mathrm{mL}^{-1}$ and $0.5 \mathrm{mg} \cdot \mathrm{mL}^{-1}$.

When newspaper (Fig. 4) was saccharified with $T$. viride cellulase a relative high amount of sugar was released during

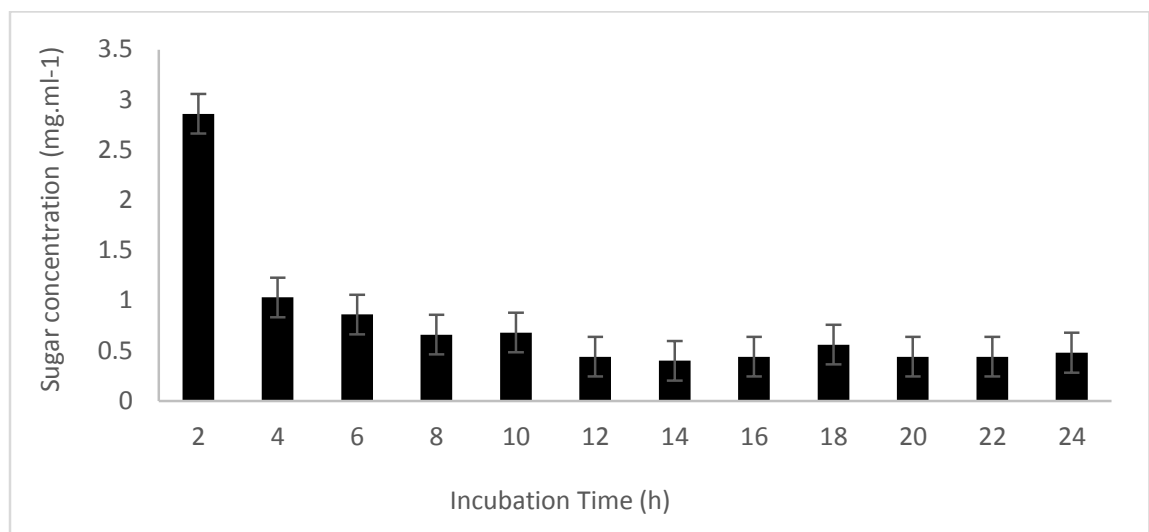

Fig. 1: The amount of sugar released during successive treatment of office paper with $T$. viride cellulase enzyme.

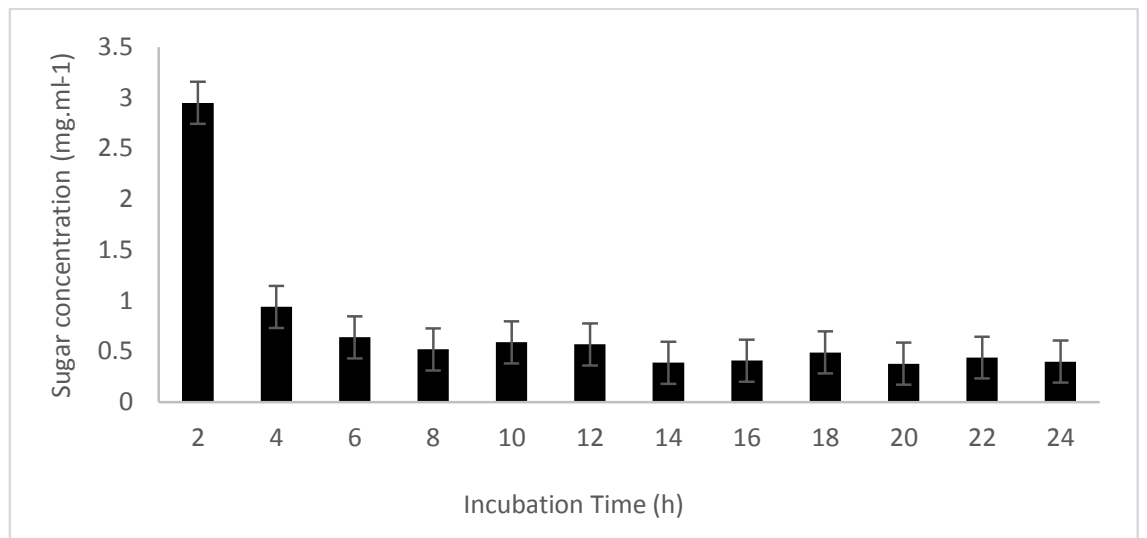

Fig. 2: The amount of sugar released during successive treatment of foolscap paper with $T$. viride cellulase enzyme. 


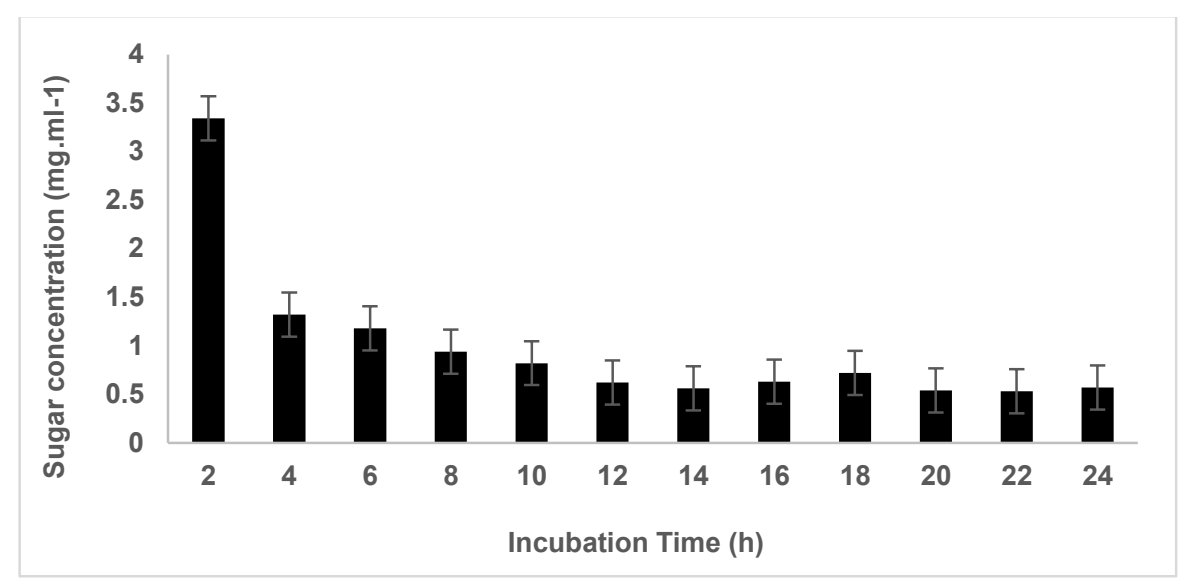

Fig. 3: The amount of sugar released during successive treatment of brown envelope paper with $T$. viride cellulase enzyme.

the first incubation period $\left(1.5 \mathrm{mg} \cdot \mathrm{mL}^{-1}\right)$ as well as during the second incubation period when sugar at a concentration of $1.4 \mathrm{mg} . \mathrm{mL}^{-1}$ was released. The amount of sugar released during the third incubation period decreased to a concentration of $0.6 \mathrm{mg} . \mathrm{mL}^{-1}$ which stayed relatively constant for the following two incubation periods. During incubation period number six $(12 \mathrm{~h})$ the sugar concentration decreased to an amount of $0.3 \mathrm{mg} . \mathrm{mL}^{-1}$ which increased to a concentration of $0.6 \mathrm{mg} . \mathrm{mL}^{-1}$ after $18 \mathrm{~h}$ of incubation and finally it decreased to $0.4 \mathrm{mg} \cdot \mathrm{mL}^{-1}$ after $24 \mathrm{~h}$ of incubation. The rate of sugar released during the first $6 \mathrm{~h}$ of incubation was calculated at $-0.15 \mathrm{mg} \cdot \mathrm{mL}^{-1}$.

When the cellulose content of Woolworths paper (Fig. 5) was bioconverted into sugars the amount of sugars released during the first two incubation periods was also relatively high at concentrations of $1.2 \mathrm{mg} \cdot \mathrm{mL}^{-1}$ and $1.0 \mathrm{mg} \cdot \mathrm{mL}^{-1}$. This observation was almost similar to the sugar releasing pattern obtained during the degradation of newspaper (Fig.
4). During the third and fourth incubation period, the sugar concentration was lower at $0.6 \mathrm{mg} . \mathrm{mL}^{-1}$, followed by a higher sugar concentration produced at $0.8 \mathrm{mg} \cdot \mathrm{mL}^{-1}$ produced during the $5^{\text {th }}$ incubation period, after $10 \mathrm{~h}$ of incubation. After the $12^{\text {th }}$ hour incubation period a lower sugar concentration was produced at a concentration of $0.3 \mathrm{mg} \cdot \mathrm{mL}^{-1}$ which varied between this value and $0.5 \mathrm{mg} \cdot \mathrm{mL}^{-1}$ sugar concentration produced during the $18 \mathrm{~h}$ of incubation with a final sugar concentration of $0.4 \mathrm{mg} . \mathrm{mL}^{-1}$ released during the last incubation period after $24 \mathrm{~h}$ of successive incubation.

Fig. 6 reflects the sugar formation from Pick 'n Pay advertising paper during successive treatment with $T$. viride cellulase. The decline of sugar formation during the initial phase of saccharification was similar to the tendency observed during cellulase catalysed degradations of the other paper materials with values changing from $0.6 \mathrm{mg} \cdot \mathrm{mL}^{-1}$ to $0.3 \mathrm{mg} \cdot \mathrm{mL}^{-1}$ during the first three consecutive periods of saccharification. From the third period of incubation to the

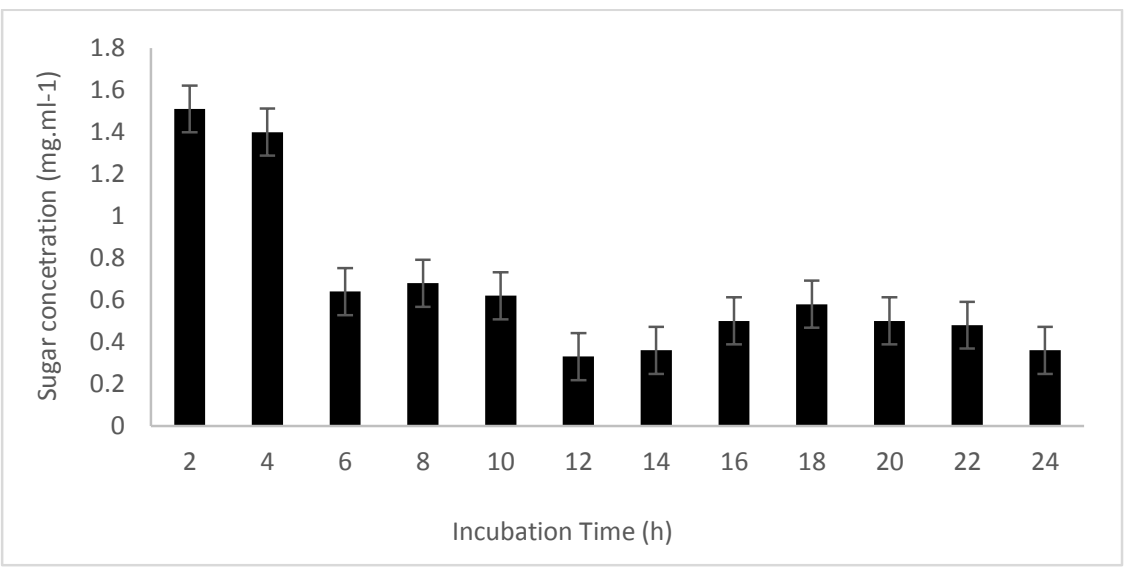

Fig. 4: The amount of sugar released during successive treatment of newspaper with $T$. viride cellulase enzyme. 


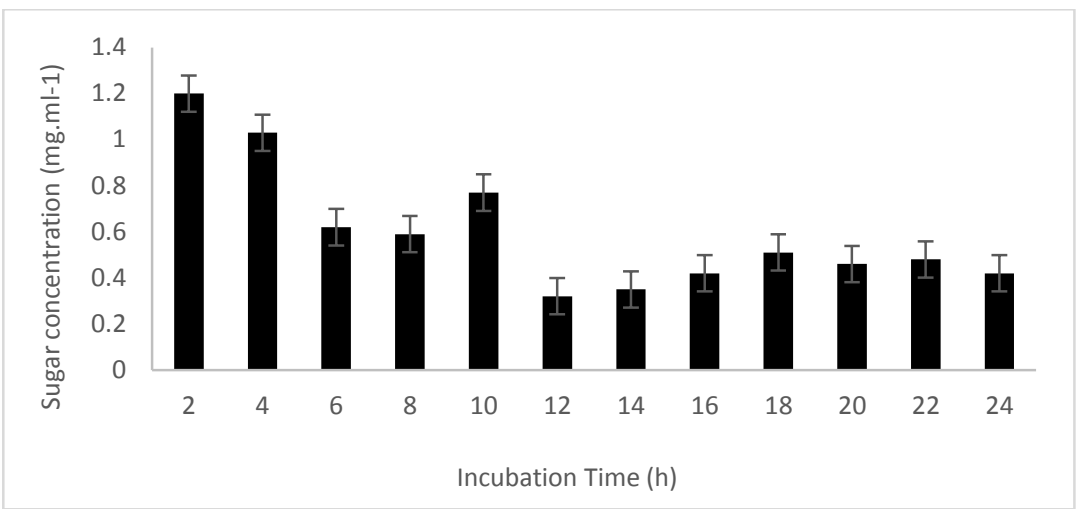

Fig. 5: The amount of sugar released during successive treatment of Woolworths paper with $T$. viride cellulase enzyme.

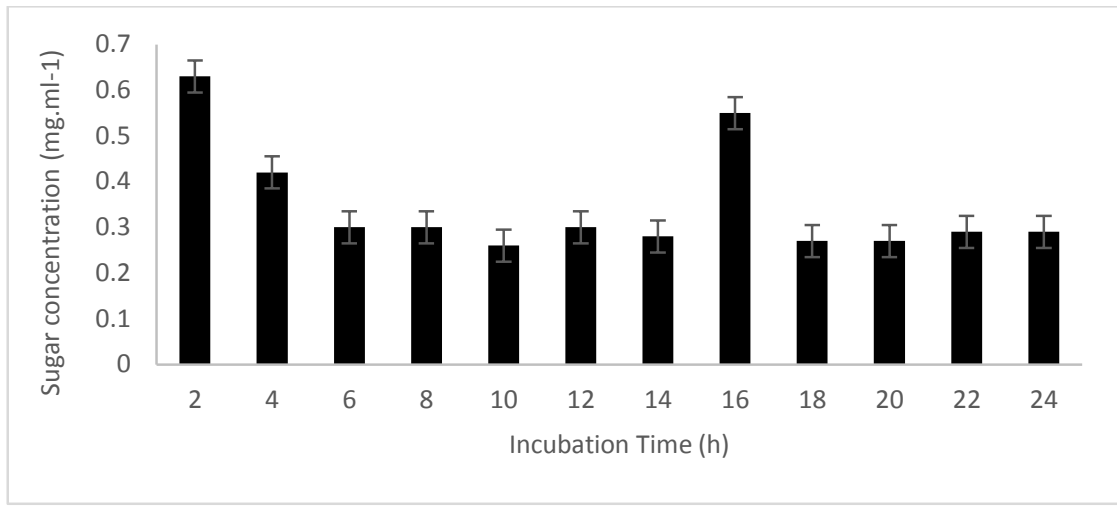

Fig. 6: The amount of sugar released during successive treatment of Pick 'n Pay paper with $T$. viride cellulase enzyme.

$7^{\text {th }}$ incubation period the amount of sugar produced stays constant at $0.3 \mathrm{mg} \cdot \mathrm{mL}^{-1}$ with an increased amount of sugar produced during the $8^{\text {th }}$ incubation period at a concentration of $0.6 \mathrm{mg} \cdot \mathrm{mL}^{-1}$ while the decline in sugar production produced during the first three incubation period was calculated at $-0.05 \mathrm{mg} \cdot \mathrm{mL}^{-1} \cdot \mathrm{h}^{-1}$. After the $8^{\text {th }}$ incubation period, the sugars concentration produced during each incubation was almost identical at $0.3 \mathrm{mg} \cdot \mathrm{mL}^{-1}$.

The successive cellulase catalysed degradation of Pick 'n Pay advertising paper (Fig. 7) exhibited a sugar releasing pattern different to the patterns observed with other paper materials. Opposed to the other paper materials which

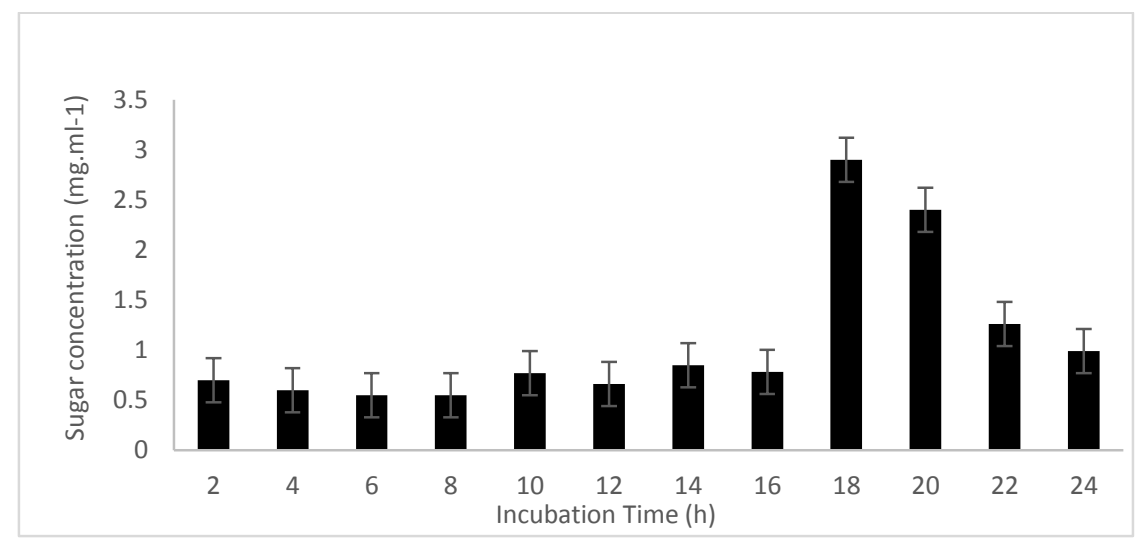

Fig. 7: The amount of sugar released during successive treatment of filter paper with $T$. viride cellulase enzyme. 
resulted in maximum sugar production during the first two incubation periods, maximum sugar concentration released from Pick ' $n$ Pay paper was observed during the ninth incubation period with the final incubation period producing more sugar than any of the first eight incubation periods. The amount of sugar produced during the first eight incubation periods varied between $0.44 \mathrm{mg} \cdot \mathrm{mL}^{-1}$ and $0.7 \mathrm{mg} . \mathrm{mL}^{-1}$ while the highest sugar concentration of $2.9 \mathrm{mg} \cdot \mathrm{mL}^{-1}$ was obtained during the ninth incubation period.

From Table 1 it can be concluded that the highest total amount of sugar $(13.1 \mathrm{mg})$ was released from filter paper during all 12 successive saccharification periods when degraded with $T$. viride cellulase. The second-highest amount of sugar was released from brown envelope paper at a mass of 11.5 $\mathrm{mg}$, followed by office paper which degradation resulted in a mass of $9.0 \mathrm{mg}$ sugar. The lowest mass of sugar production was released from Pick ' $n$ Pay advertising paper which resulted in a mass of $4.2 \mathrm{mg}$. The average sugar concentration produced during the total degradation period follows the same tendency as the total masses of sugar released from various paper materials with the highest sugar concentration produced at a concentration of $1.09 \mathrm{mg} \cdot \mathrm{mL}^{-1}$ when filter paper was degraded and the lowest sugar concentration $(0.35$ mg. $\mathrm{mL}^{-1}$ ) released from Pick 'n Pay advertising paper.

The percentage saccharification of the various paper materials is a way to compare the relative susceptibility of the paper materials to be degraded by $T$. viride cellulase. From the saccharification results presented in Table 1, it can be concluded that filter paper was the most effectively degraded when exposed to successive degradation followed by the newspaper, and foolscap paper. The paper material producing the least amount of sugar was Pick 'n Pay advertising paper resulting in $15 \%$ degradation followed by brown envelope paper that was degraded to an extent of $17 \%$. The observation that most of the paper materials produced a maximum amount of sugar during the first incubation period suggests that the amorphous section of cellulose (easily degradable) is more exposed to cellulase action (Hall et al. 2010, Beyene et al. 2017). After the first period of degradation, the relative amount of the crystalline section (difficult to degrade) has increased resulting in a lower degree of saccharification (Taherzadeh \& Karimi 2008). The fact that Woolworths paper, Pick ' $n$ Pay advertising paper and filter paper showed an increase in saccharification during the latter phases of degradation could be the result of the crystalline sections that were initially more exposed to the cellulase action with the amorphous cellulose becoming more available as the crystalline sections are hydrolysed.

The different sugar releasing patterns obtained during the cellulase catalysed bioconversion of seven different paper materials could be attributed to several factors such as the structural composition of the cellulase enzyme (Yang et al. 2011, Gandu et al. 2018), the chemical structure of the paper materials (Sahin \& Arslan 2008) and additives, fillers and glaziers used as a part of the paper materials (Hubbe \& Gill 2016).

With the annual global generation of solid waste reaching almost 20 billion tons and estimated amounts to be 27 billion tons by 2050 , it is imperative that solid waste of which waste paper is a major component be considered as a possible feedstock rather than waste which has to be incinerated or be managed at dumping sites (Laurent et al. 2014). The waste

Table 1: Relative percentage saccharification of various paper materials when degraded with T. viride cellulase.

\begin{tabular}{|c|c|c|c|c|c|c|}
\hline Paper material & $\begin{array}{l}\text { Incubation period } \\
\text { resulting in high- } \\
\text { est sugar concen- } \\
\text { tration }\end{array}$ & $\begin{array}{l}\text { Sugar concentration } \\
\text { produced during in- } \\
\text { cubation period re- } \\
\text { sulting in maximum } \\
\text { sugar concentration } \\
\left(\mathrm{mg} \cdot \mathrm{mL}^{-1}\right)\end{array}$ & $\begin{array}{l}\text { Total sugar } \\
\text { produced dur- } \\
\text { ing } 12 \text { succes- } \\
\text { sive degrada- } \\
\text { tion periods } \\
(\mathrm{mg})\end{array}$ & $\begin{array}{l}\text { Average sugar } \\
\text { concentration af- } \\
\text { ter } 12 \text { successive } \\
\text { degradation pe- } \\
\text { riods } \\
\left(\mathrm{mg} \cdot \mathrm{mL}^{-1}\right)\end{array}$ & $\begin{array}{l}\text { Mass of paper } \\
\text { degraded } \\
(\mathrm{mg})\end{array}$ & $\begin{array}{l}\text { Percentage sacchari- } \\
\text { fication after } 12 \text { suc- } \\
\text { cessive degradation } \\
\text { periods } \\
(\%)\end{array}$ \\
\hline Office paper & 1 & 2.8 & 9.0 & 0.75 & 44 & 20 \\
\hline Foolscap paper & 1 & 3.0 & 8.6 & 0.72 & 35 & 25 \\
\hline $\begin{array}{l}\text { Brown Envelope } \\
\text { Paper }\end{array}$ & 1 & 3.3 & 11.5 & 0.95 & 66 & 17 \\
\hline Newspaper & 1 & 1.5 & 8 & 0.66 & 28 & 28 \\
\hline $\begin{array}{l}\text { Woolworths Adver- } \\
\text { tising Paper }\end{array}$ & 1 & 1.2 & 7.2 & 0.6 & 41 & 18 \\
\hline $\begin{array}{l}\text { Pick 'n Pay Adver- } \\
\text { tising Paper }\end{array}$ & 1 & 0.6 & 4.25 & 0.35 & 28 & 15 \\
\hline Filter Paper & 9 & 2.9 & 13.1 & 1.09 & 37 & 35 \\
\hline
\end{tabular}


management change is already evident as the waste paper is investigated as a resource for the production of biomethane (Li et al. 2020, Takizana et al. 2019), nano-cellulose (Kumar et al. 2020, Putro et al. 2019), levulinic acid (Dutta et al. 2020) and bio-hydrogen (Poladyan et al. 2020). All these processes require the saccharification of the cellulose component of waste paper and thus it is one of the important observaitons of this study which illustrates the difference in sugar-producing profiles and sugar yields when bioconverted successively with fresh cellulase enzyme.

\section{CONCLUSIONS}

The increasing global population is producing more waste that needs to be managed to ensure a clean and healthy environment. Paper products are utilized by all global communities and it is a major component of solid waste with cellulose, a structural component of waste paper and glucose-based polymer also treated as waste as a result of traditional waste management procedures. Waste cellulose has the potential to be bio-converted into glucose a fermentable sugar through the catalytic action of cellulase, a hydrolytic enzyme. For the saccharification process to be more effective it is important that the waste bioconversion process is substrate specific as concluded from this investigation as each paper material exhibits a unique sugar releasing profile when bio-treated with cellulase enzymes. The successive treatment of cellulose relies on the continuous removal of glucose, a reaction product which limits the possibility of end-product inhibition and as a result the extent of the saccharification process. Results obtained from this investigation also suggests that different waste paper materials should be incubated separately with cellulase enzymes rather than a mixture of paper materials. It is also no guarantee that the degradation of a specific paper material will follow the same degradation pattern when exposed to other cellulase enzymes. The cellulase catalysed bioconversion of cellulose is an extremely complex procedure with a number of variables that should be optimized for maximally sugar production from the waste cellulose. Successive cellulase treatment of these waste materials is only a single hydrolytic factor that should be optimized for the effective degradation of waste cellulose materials.

\section{REFERENCES}

Alrumma, S.A. 2016. Enzymatic saccharification and fermentation of cellulosic date palm wastes to glucose and lactic acid. Braz. J. Microbiol., 4(1): 110-119.

Beyene, D., Chae, M., Dai, J., Danumah, C., Tosto, F., Demesa, A.G. and Bresler, D.A. 2017. Enzymatically-mediated co-production of cellulose nanocrystals and fermentable sugars. Crystals, 7(11): 322-328.

Canilha, L., Rodrigues, R.L.B., Antunes, F.A.F., Chandel, A.K., Milessi, T.S., Felipe, M.A. and Silverio DaSilva, S. 2013. Bioconversion of hemicellulose from sugarcane biomass into sustainable products.
IntechOpen, 15-45.

Dutta, S., Yu, I.K.M., Tsang, D.C.W., Su, Z., Hu, C., Wu, K.C., Yip, A.C.K., Ok, Y.S. and Poon, C.S. 2020. Influence of green solvent on levulinic acid production from lignocellulosic paper waste. Bioresour. Technol., 298: 122544

Gandu, M.L., Martin, C. and Jonsson, L.J. 2018. Analytical enzymatic saccharification of lignocellulosic biomass for conversion to biofuels and bio-based chemical. Energies, 11: 1-20.

Hall, M., Bansal, P., Lee, J.H., Realff, M.J. and Bommarius, A.S. 2010. Cellulose crystallinity-a key predictor of the enzymatic hydrolysis rate. FEBS J., 277: 1571-1582.

Hamelinck, C.N., Hooijdonk, G. and Faaij, A.P.C. 2005. Ethanol from lignocellulosic biomass: techno-economic performance in short-, middle- and long-term. Biomass and Bioenergy, 28: 384-410.

Hubbe, M.A. and Gill, R.A. 2016. Fillers for papermaking: A review of their properties, usage practices and their mechanistic role. Bioresources, 11(1): 2886-2963.

Jeoh, T., Wilson, D.B. and Walker, L.P., 2006. Effect of cellulase mole fraction and cellulose recalcitrance on synergism in cellulose hydrolysis and binding. Biotechnol. Prog., 22: 270-27.

Kim, E., Irwin, D.C., Walker, L.P. and Wilson D.B. 1998. Factorial optimization of a six-cellulase mixture. Biotechnol. Bioeng., 58: 494-501.

Kumar, V., Pathak, P. and Bhardwaj, N.K. 2020. Waste paper: An underutilized but promising source for nanocellulose mining. Waste Manage., 102: 208-303.

Laurent, A., Bakas, I., Clavreul, J., Bernstad, A., Niero, M., Gentil, M.Z. and Hauschild, T.H. 2014. Review of LCA studies of solid waste management system: Lessons learned and perspectives. Waste Manage., 34(3): 573-588.

Li, W., Khalid, F., Amin, F., Zhang, H., Dai, Z., Cheng, C. and Liu, G. 2020. Biomethane production characteristics, kinetic analysis, and energy potential of different paper wastes in aerobic digestion. Renew. Energy, In press.

Loelovich, M. 2014. Waste paper as a promising feedstock for production of biofuel. J. Sci. Res. Rep., 3(7): 905-917.

Mazzoli, R. 2012. Development of microorganisms for cellulose-biofuel consolidated bio-processings: Metabolic engineers' tricks. Computational and Structural. Biotechnol. J., 3(4): e201210007.

Miller, G.L. 1959. Use of dinitrosalicylic acid reagent for determination of reducing sugar. Anal. Chem., 31: 426-428.

Ndlovu, T.M. and Van Wyk, J.P.H. 2019. Relative saccharifiction of waste paper during successive treatment with garden snail (Cornu aspersum) cellulase. Sustain. Chem. Pharm., 11: 54-60.

Poladyan, A., Margaryan, L., Trchounian, K. and Trchounian, A. 2020. Biomass and biohydrogen production during dark fermentation of $E s$ cherichia coli using office paper waste and cardboard. Int. J. Hydrog. Energy, 45(1): 286-293.

Putro, J.N., Santoso, S.P., Soetaredja, F.E., Ismadji, S. and Ju, Y. 2019. Nanocrystalline cellulose from waste paper: Adsorbent for azo dyes removal. Environ. Nanotechnol. Monit. Manag., 12: Article 100260.

Rodriguez, C., Alaswad, A., Hassen, Z. and Olabi, A.G. 2017. Improvement of methane production from $P$. canaliculata through mechanical pretreatment. Renew. Energy, 119: 73-78.

Sahin, H.J. and Arslan, M.B. 2008. A study on physical and chemical properties of cellulose paper immersed in various solvent mixtures. Inter. J. Mol. Sci., 9(1): 78-88.

Saini, J.K., Saini, R. and Tewari, L. 2015. Lignocellulosic agriculture wastes as biomass feedstocks for second-generations bioethanol production: concepts and recent developments. 3 Biotech, 5: 337-353.

Seidl, P.R. and Goulart, A.K. 2016. Pretreatment processes for lignocellulosic biomass conversion to biofuels and bioproducts. Curr. Opin. Green Sustain. Chem., 2: 48-53.

Taherzadeh, M.J. and Karimi, K. 2008. Pretreatment of lignocellulosic wastes to improve ethanol and biogas production. Int. J. Mol. Sci., 9(9): 1621-1651. 
Tahir, M., Hussain, T. and Behaylu, A. 2015. Scenario of present and future of solid waste generation in India: A case study of Delhi Mega City. J. Environ. Earth Sci., 5(8): 83-91.

Takizana, S., Baba, Y., Tada, C., Fuuda, Y and Nakai, Y. 2019. Preservation of rumen fluid for the pretreatment of waste paper to improve methane production. Waste Manage., 87: 672-678.

Van Wyk, J.P.H., Mogale, M.A. and Moroka, K.S. 1999. Bioconversion of waste paper materials to sugars: an application illustrating the environmental benefit of enzymes. Biochem. Educ., 27: 227-229.
Veluchamy, C., Raju, V.W. and Kalamdhad, A.S. 2017. Electrohydrolysis pretreatment for enhanced methane production from lignocellulose waste pulp and paper mill sludge and its kinetics. Biores. Technol., 252: $52-58$.

Wu, C. and Cheng, C. 2005. A study of the hydrolysis of waste paper cellulose with a vertically hanging immobilized cellulase reactor and the reuse of the immobilized cellulase. J. Chin. Chem. Soc., 52: 85-95.

Yang, B., Dai, Z., Ding, S. and Wyman, C.E. 2011. Enzymatic hydrolysis of cellulosic biomass. Biofuels, 2(4): 421-450. 